\title{
New trends in financial service delivery and corporate/individual customers' financial adjustments consequent upon the COVID-19 global pandemic
}

\author{
Okey Peter Onyia ${ }^{1}$
}

Accepted: 6 October 2021 / Published online: 27 October 2021

(c) The Author(s), under exclusive licence to Springer Nature Limited 2021

COVID-19 has been labelled the "Black Swan Risk" (Antipova, 2020), which has affected the lives of businesses and societies around the entire world. As of 5:15 pm CEST, October 06,2020 , there were precisely $33,347,404$ confirmed cases of COVID-19 infections globally, including $1,039,406$ deaths, as reported by the World Health Organization (WHO, 06/10/2020). Exactly one year later, on October 06,2021 , there were $235,175,106$ confirmed cases of infections and 4,806,841 deaths globally attributed to COVID-19 (WHO, 06/10/2021).

In terms of economic impact, the global pandemic is reported to have caused a steep decline of about $6.5 \%$ in the world's economic growth between 2019 and 2020 . The cumulative global GDP loss from 2020 to 2025 has been projected to a massive \$S35 trillion (McKibbin and Vines 2020). Across sectors, the global tourism, logistics and financial industries have been the three sectors most adversely hit by the pandemic. The United Nations Conference on Trade and Development (UNCTAD) reported in June 2021 that the global GDP loss due to the impacts of COVID-19 on global tourism could be over $\$ 4$ trillion dollars between the years 2020 and 2021. In addition, the global financial stock market index fell by about $27 \%$ before the mid-2021. As a result, the pandemic triggered a rush for liquidity ("dash for cash"), with hurried sales of risky assets for cash and purchases of less risky assets around the world.

The wave of panic in response to the global pandemic has been stronger in emerging and frontier markets and has caused large revenue and asset losses (Wójcik and Ioannou 2020). In the global banking and financial industry, the pandemic has also caused grave disruptions in business operations and service delivery, with critical implications for both

Okey Peter Onyia

OkeyPeterOnyia@uowdubai.ac.ae

1 Faculty of Business, University of Wollongong in Dubai, Knowledge Park, Dubai, UAE the financial institutions and their corporate and individual customers. The disruptive consequences necessitated an urgent need for different strategies in financial services marketing, service innovations, corporate and personal financial planning, and the customer cum service-provider interactions and relationships. Since the COVID-19 pandemic first broke out in December 2019, more and more challenges in business innovations, service delivery, and customer relationships have continued to evolve up to date.

This Special Issue of the Journal of Financial Services Marketing provides academic researchers and industry managers in the financial and other related industrial sectors a comprehensive update of the latest empirical research reports on the economic disruptions and business operational challenges occasioned by the sudden breakout of the COVID-19 pandemic in China in December 2019, as well as its rapid spread around the world in the first quarter of 2020. Also highlighted in some of the papers in this special issue are the novel business strategies devised and implemented by businesses in various industrial sectors in response to the pandemic. The aim is to avail global financial service institutions, financial products marketers, and their corporate/retail customers a source of empirical information on the way forward in strategically dealing with the disruptive impacts of the global pandemic.

The idea of our special issue theme is to leverage one of the most topical issues around the world today-the impacts of the global Covid-19 pandemic and its attendant lockdowns in most countries around the world during its first ear (2020) on both financial service providers and their corporate/individual customers. Specifically, the research papers in this issue have investigated and documented the impacts of the pandemic on the marketing and delivery of financial institutions' services in various countries, as well as on their corporate and individual customers' financial and operational strategies. Only the most excellent original research papers have been selected and published in this 
special issue. They cover aspects of the impacts of, and response to, the global pandemic relating (but not restricted) to the economic and financial activities of the various financial and non-financial global industries.

The responses include some disruptive innovations, changes in business models, new service trends, new modus operandi in business, and new best practices in the corporate financial customers' business and marketing activities in response to the pandemic. Other aspects examined by contributors include the impacts of the Covid-19 pandemic on the individual customers of banks and non-bank financial institutions-including the reactive adjustments, new thought-processes, and other changes they have implemented in their financial planning behaviours and spending activities - as a result of the global pandemic and its attendant disruptions in the first 12 months of the pandemic. We are sure that readers will find these special issue articles not only informative and educational, but also pleasurable to read.

\section{References}

Antipova, T. 2021. Coronavirus Pandemic as Black Swan Event. In Integrated Science in Digital Age 2020. ICIS 2020. Lecture
Notes in Networks and Systems, vol. 136, ed. T. Antipova. Cham: Springer. https://doi.org/10.1007/978-3-030-49264-9_32.

McKibbin, W., \& Vines, D. 2020. Global Macroeconomic Cooperation in Response to the COVID-19 Pandemic: A Roadmap for the G20 and the IMF. Oxford Review of Economic Policy, 1-41.

UNCTAD. 2021. United Nations Conference on Trade and Development. https://unctad.org/news/global-economy-could-lose-over4-trillion-due-covid-19-impact-tourism. Accessed on 06 October, 2021.

WHO. 2020 and 2021. World Health Organization Daily Coronavirus Update. https://www.who.int/emergencies/diseases/novel-coron avirus-2019. Accessed 6 Oct 2021.

Wójcik, D., and S. Ioannou. 2020. COVID-19 and Finance: Market Developments So Far and Potential Impacts on the Financial Sector and Centres. Tijdschrift Voor Economische En Sociale Geografie 111 (3): 387-400.

Publisher's Note Springer Nature remains neutral with regard to jurisdictional claims in published maps and institutional affiliations. 